\section{Very Low Temperatures}

\section{Exhibition at the Science Museum}

"T HE function of a science museum does not end with the record of the achievements of thought and invention of the past; it is also its duty to show the continuous progress of the present". These words were spoken by Sir William Bragg, when he opened the Exhibition of Very Low Temperatures at the Science Museum on March 4. Before a distinguished audience he recalled that one hundred and forty years ago Benjamin Thompson, Count Rumford, wrote a description of what he considered the ideal science museum should be. He was ahead of his time, however, and an attempt to found such a museum at the Royal Institution was a failure.

The Royal Institution has fulfilled another role, and in the Science Museum at South Kensington Rumford's ideals have been achieved. The valuable historical material which is housed there has taken more than three-quarters of a century to collect, but it is only in comparatively recent years, under the stimulus of the late director, Sir Henry Lyons, and of his successor, Colonel E. E. B. Mackintosh, that its second duty, that of showing the "continuous progress of the present", has been attempted, and of this the present exhibition is an outstanding example.

Lord Rayleigh presided at the opening ceremony. In seconding a vote of thanks proposed by Mr. H. T. Tizard (chairman of the Exhibition Committee), Colonel Mackintosh referred to the fact that it was Prof. P. Kapitza who, during the preparation of the Refrigeration Exhibition held in the Museum two years ago, suggested that the very low temperature section should be omitted and treated some day as a separate exhibition. Mr. T. C. Crawhall, an officer of the Museum, has had charge of the arrangements for both exhibitions and has also acted as secretary of the Exhibition Committee. Among those present were Dr. J. Donald Pollock, by whose personal generosity many of the exhibits have been acquired.

The exhibition, which will be on view until May 31, is unique in conception and ambitious in character, the exhibits having been devised in most cases so that they can be operated by the visitor. Some of them have been made for the exhibition by industrial firms, all of whom have contributed anonymously, while others have been made in the Museum to the designs of Dr. O. Kantorowicz, who has been specially engaged for the duration of the exhibition. The difficulties of constructing apparatus which will demonstrate physical principles in as simple a manner as possible are well enough appreciated, but to make these in such a way that they can be operated continuously by visitors to a museum, which has been so successfully achieved in this exhibition, is worthy of great praise.

The exhibits are grouped under the following headings: temperature reduction, temperature and pressure measurement, liquefaction and solidification, storage and transport, applications, properties and historical. Demonstrations involving the use of solid carbon dioxide and liquid air are given at intervals throughout the day by attendants, while a series of lectures, which will include demonstrations at the very low temperatures, is being arranged. Details of the lectures will be published as soon as possible.
For those who want to make a study of the achievements of the past a collection of apparatus from several places in Great Britain and the Continent is available. These illustrate the work of Andrews, Claude, Dewar, de Haas, Faraday, Joule, Kamerlingh Onnes, Keesom, Linde, Olszewski, Wroblewski, Ramsay and Travers, the Continental exhibits having come from Cracow, Leyden, Munich and Paris, while the others have been received from the Royal Institu. tion and the Manchester College of Technology, in addition to those transferred from other sections of the Science Museum.

A small handbook entitled "Very Low Tempers. tures", giving a brief survey of the physical principles underlying the attainment of very low temperatures and of their uses, has been prepared by Mr. Crawhall and is on sale at the Museum, price $6 d$. net $(7 d$. including postage).

\section{Educational Topics and Events}

Cambridas.--Smith's Prizes have been awarded to A. E. Green, of Jesus College, and A. M. Turing, of King's College.

Rayleigh Prizes have been awarded to S. W. Shiveshwarkar, of Sidney Sussex College, E. T. Goodwin, of Peterhouse and D. M. A. Leggett, of Trinity College.

At St. John's College a research studentship and research exhibitions are offered for competition in July. One Stratheona research studentship of the annual value of $£ 200$ is offered for competition among research students who are $(a)$ graduates of any university other than Cambridge or $(b)$ graduates of Cambridge who are not already members of St. John's College. Two Stratheona exhibitions of the annual value of $£ 40$ are also offered for competition under the same conditions as the studentship. In special circumstances a supplementary payment may be made to exhibitioners. The election of a candidate is subject to his being accepted by the University as a research student proceeding to the $\mathrm{Ph} . \mathrm{D}$. degree, and if he is not yet a member of the College, to his beginning residence at the College in October 1936.

Dr. J. A. Venn, president of Queen's College, has issued an appeal in connexion with the publication of "Alumni Cantabrigienses". The four volumes of Part 1, containing biographies (nearly 80,000 in number) of all recorded members of this University from the earliest times up to 1751 , were published by the Cambridge University Press in the years that immediately followed the Great War. Part 2, covering entrants from 1752 until 1900, will be passing through the Press during the next four or five years, and in order that this section may be as complete as possible, an appeal is being made to biographers, genealogists, historians and also old Cambridge men themselves, for biographical facts relating to any man who matriculated at the University or was admitted to any College between January 1, 1752, and December 31, 1900. All informa. tion should be sent direct to Dr. Venn.

London.-The Graham Legacy Committee has, under the regulations for the administration of the Charles Graham Medical Research Fund, awarded a Gold Medal of the value of $£ 20$ to Sir Thomas 
Lewis, physician in charge of the Department of Clinical Research at University College Hospital, for research work in connexion with the treatment of cardiac disease.

The following have been appointed fellows of King's College: Prof. Gilbert Cook, professor of mechanical engineering since 1921 and now head of the Department of Civil and Mechanical Engineering ; Sir Halley Stewart, who is chairman of the Halley Stewart Trust, which has greatly enhanced the facilities for research in physics by placing 30 Chester. ford Gardens at the disposal of the College and by the endowment of the research earried on therein; Dr. J. W. Pickering, formerly a student of the College and since 1923 honorary lecturer in physio$\operatorname{logy}$; Mr. C. K. Bird, a student in the Faculty of Engineering in 1904-8 and who, since the War, has achieved a distinguished position in another profession under the nom de plume of "Fougasse".

The following have been appointed fellows of University College, London: Prof. N. H. Baynes, professor of Byzantine history in the University; Prof. F. G. Donnan, professor of chemistry in the University; Dr. H. P. Himsworth, deputy director of the Medical Unit at University College Hospital Medical School; Dr. R. J. Ludford, honorary lecturer in cytology at University College; Dr. A. S. MacNalty, Chief Medical Officer, Ministry of Health; Mr. F. Norman, reader in German at University College and King's College; Mr. Julian Taylor, assistant surgeon, University College Hospital; Dr. F. C. Toy, deputy director of the British Cotton Industry Research Association.

Applicatrons, which must be received not later than April 15, are invited for the following scholarships awarded by the Institution of Electrical Engineers: Duddell Scholarship (value $£ 150$ per annum, tenable for three years), open to British subjects less than nineteen years of age on July 1, 1936, who have passed the matriculation examination of a British university. Ferranti Scholarship (value $£ 250$ per annum, tenable for two years), open to British subjects less than twenty-six years of age on July 1, 1936, who are students or graduates of the Institution and have been such for not less than two years. Swan Memorial Scholarship (value $£ 120$, for one year), open to British subjects less than twenty-seven years of age on July 1, 1936, who have completed a recognised course in electrical engineering or science of at least three years, and who desire to carry out whole-time research or post-graduate work of an electrical engineering nature. Silvanus Thompson Scholarship (value $£ 100$ per annum and tuition fees, tenable for two years), for works employees who are the sons of parents of limited means, open to British subjects less than twenty-two years of age on July 1, 1936. William Beedie Esson Scholarship (value $£ 120$ per annum, tenable for two years, renewable in approved cases for a third year), open to British subjects who are less than twenty-two years of age on July 1, 1936, have served a minimum apprenticeship (or its equivalent) of three years at an approved electrical engineering works, and desire to take up a whole-time day course in electrical engineering at an approved university or technical college. Further particulars can be obtained from the Secretary, Institution of Electrical Engineers, Savoy Place, London, W.C.2.

\section{Science News a Century Ago}

\section{Steam Navigation in the Red Sea}

IN a paper by Lieut. Wellsted "On the West Coast of Arabia, from Ras Mohammed to Jidda", read on March 14, 1836, before the Royal Geographical Society, reference was made to the reefs which lie off the coast and extend considerable distances with navigable channels inside them. Writing at a time when steam navigation to India was frequently being discussed, Lieut. Wellsted said: "It has sometimes been debated whether, if a small steam boat were employed, the mails might not be conveyed up and down the Red Sea inside these reefs, more easily than without them; especially as their influence in destroying any wind, however strong, blowing against them was very remarkable. The passages inside the reefs were very numerous but it would be necessary to anchor each night. But both coal and other wear and tear would be saved and the route is unquestionably practicable".

\section{The Statistical Society}

AT the anniversary meeting of the Statistical Society held on March 15, 1836, Henry Hallam, the honorary treasurer, being in the chair, the report of the Council said the Society had 392 members. It was also remarked that "the early progress of a society, which has for its object, not the establishment of a particular theory or the development of any particular science but an enquiry into the various and innumerable relations existing among men and nations, must necessarily be slow-that the usefulness of such a Society cannot be estimated by the apparent amount of its labours or the number of its publications - that its fruits will become visible in an awakened spirit of research".

\section{Royal Asiatic Society and Indian Agriculture}

At a general meeting of the Royal Asiatic Society held on March 19, 1836, the Right Hon. H. Mackenzie and Mr. J. F. Royle made the suggestion that a committee on trade and agriculture should be appointed to inquire into the capabilities of the various soils and climates of India with the view of stimulating production. Mr. Royle exhibited a collection of vegetable and mineral products from India, and in the course of his remarks said that by the application of science, especially of botany and meteorology, much might be done to increase the comforts and resources of the natives of India. That such views were not chimerical might be seen by looking at the rise and progress of the trade in indigo, opium, lac, cotton and more recently catechu, safflower, linseed and rapeseed. In proposing that the Society should investigate the production and inquire into the processes of cultivation of the East, and apply to their improvement the science of the West, he considered he was taking the only satisfactory and legitimate means of attaining the object in view-the improvement of the resources of India.

\section{Herschel's Supposed Discoveries in the Moon}

The extraordinary hoax perpetrated by Richard Adams Locke in the newly-founded New York Sun regarding the discoveries said to have been made by Sir John Herschel at the Cape, to which reference was made in NATURE of January 13, 1934, p. 73, found an echo in The Times of March 21, 1836, 